\title{
The garden of Burle Marx in the Palace of the Lions in the city of St. Luis, Brazil
}

\author{
B. I. Wasinski Prado \\ Department of Architecture and Urbanism, \\ State University of the Maranhão, Brazil
}

\begin{abstract}
Heritage and design are two terms that refer to the past and the future respectively. This paper discusses landscape design and its features about the past and the importance, to the future, of perpetuating these values. The debate is about the objective and subjective values which matter so much to the past, about the future of local and national culture, in the complex dialogue between the past and the future of the landscape work of the Lions Palace Gardens in St. Luis, Maranhão, Brazil. This "open space" has been part of an architectural and landscape urban historical, since 1614. These values are, also expressed in the garden through Roberto Burle Marx's design, built in 1968 and in 1973 and mischaracterized over time. The garden transformations were studied by historiography and morphological analysis. It is considered that today, in the case of an intervention, the modernist values that we are interested in preserving, it should be highlighted as an original product of Brazilian thought and of their "doing of the thing", and especially those values that would be capable of enjoyment in the future. The work of Roberto Burle Marx deserves to be crystallized, recovered and preserved, because it is a cultural asset, a heritage that expresses a unique landscape design that transcends the decisions of the local government.
\end{abstract}

Keywords: design, garden, heritage, Burle Marx, Palace of the Lions.

\section{Introduction}

Open space is a concept that includes many morphological typologies, like gardens, parks, boulevards, squares, plazas, streets and other types. And natural landscapes too. It's opposed to the concept of closed space - the construction 
itself, like Magnoli [1] defended. Cullen [2] said in the 60s something like that: one building is architecture: two buildings are urban landscape. It means that the urban landscape is composed of closed spaces and the open spaces, essentially.

The Palace of the Lions is the seat of government of Maranhão in Brazil, built on the founding site of the city of St. Luis. It is located on a promontory, facing the sea, on a cliff on the banks of rivers Anil and Bacanga, near the mouth of the two rivers. Looking back in time, the building was always the seat of government, in Maranhão's territory. Over time, the promontory was occupied by a fortress, which was being transformed and adapted to different social and political contexts, to become the Palace of the Lions.

The fortress was built in the 17th century, originally using wood, and then rebuilt in stone and mortar with the characteristics of military architecture of the Philippines Order.

The palace is part of an architectural, urban and landscape set that includes the buildings surrounding the Maranhense Avenue (named today Squares Pedro II), Mother D'Água and Benedito Leite. Such open spaces keep the memory and the traces of the Brazilian doings and knowledge from the indigenous knowledge. Where once was the "ocara" (place) of tupinambás (1611), described by the French Capuchin Mission, it was also a yard of São Luis Fort (1612), bastion of the top (1614), weapon's square of the fortress that defended the possessions of the French, Portuguese, Dutch and the Portuguese again between 1618 and 1821, and still other traces and other doings not been studied yet. As for today's gardens, it has always been an Open Space between the construction of the headquarters and the walls surrounding the site. The space was used for the united order, to military activities, such as patio for ammunition and weapons (there are some guns even today) and finally, to the delight of the palace, with a garden built in the middle eight hundred years.

The place's occupation history has more than 400 years and this space set is object of study, especially the open space that has remained as such after so many centuries, despite its many functions and since the 18th century is intended its most noble function - the Garden in the Palace of the Lions.

This text emphasizes the permanence of open space, today the Palace of the Lions Garden, which, for more than four centuries, remained clear, despite the changes of its responsibilities in the course of time. Also argues here, that this is one of the important historic gardens in Brazil, and it has many advantages, including one of the most significant related to the Roberto Burle Marx's interventions.

The study of the Palace of the Lions concerning its surroundings and especially its gardens, invokes the establishment of a dialogue between the past and the future of the Maranhão culture, and more, of the Brazilian culture. The stylistic palimpsest formed by the set contains fragments of various moments of local life into four centuries at least, and traces of their international cultural relations. With these initial and general considerations, we intend to demonstrate that the Palace of the Lions Garden kept architectural aspects, landscape and urban planning of historical and cultural interest, which are the essential conditions of a historical garden, as recommend the Charter of Florence, 1981. 


\section{Recovering the historic garden}

The research in many different registers, as photographic images of a lot periods, newspapers, papers, drawings and graphics surveys made it possible to understand that the open space of the Palace of the Lions had many uses, as the weapon's square and gave way to a garden in the middle of eight hundred years. Possibly, around 1857 it would have received alleys of palm trees, similar to what was being practiced in Brazil, from Rio de Janeiro and São Paulo, when the imperial palms were being planted (Roystonea oleracea), and today the plants can be seen aligned (most likely replanted in the same places) [3].

In 1901, an order of the Director of Municipal Intendencia of the Maranhão state capital, published in the "North Daily" Notice, $\mathrm{N}^{\circ} 33$, notice the embellishment project "Palace Square", where the most important buildings of the city were located, and constructions in other places and this notice shall indicate the Palmerio Carvalho Cantanhede engineer design and his replacement Anísio de Carvalho Palhano. Also determined that the implementation of embellishment should be done by the "gardener Manoel Barboza, in charge of the tree planting and care of gardens of all disposition, and whose proficiency in the subject is generally known" (North Daily, p. 4 [4]). The palace gardens were also included in this embellishment. Studies by Prado in 2007 [5], indicate that there may have been, based on the cited reform, the contribution of the architect Charles Thays and his project created in 1900, as suggested by the project published by Berjman [6]. In this project we can see the square, avenueboulevard Pedro II by the seaside (riverside) and the garden of the Palace of the Lions, in which the architect was seeking to integrate it to the riverside/seaside, through a doorway with a staircase localized in the third curtain surrounding the Palace of the Lions. Also, a new creation appears, a new bulwark between existing ones, bulwark of Cosmas and Damian. In terms of deepening, the studies of Costa and Prado [7] and Prado [5] show that it was possible to check the similarities regarding to the work's edictal, which was performed in 1904 with the architect's proposal. The rigor and care survey done in 1900 are surprising, taking into account that the French architect Charles Thays, was living in Argentina. A job that today can be compared to current geo-referenced surveys, such technical quality and care. The existence of this project and more three landscape design projects made by Charles Thays to São Luis were confirmed by publishing "News Gazeta" on 07.19.1901 announcing an exhibition at Casa Constrejan in Ouvidor Street, number 84, in Rio de Janeiro, from the model of the project Avenue-Boulevard Pedro II and the waterfront (riverside) of São Luis [8]. It should be noted also that this hygiene project is even previous to the project and work, considered urban hygienism pioneers in Brazil, at the Central Avenue in Rio de Janeiro, 1905.

In 1906, in the management of the governor Benedito Leite (1906/1908), the palace was expanded, extending a wing on his back, for the governor's residence and the facade of the palace brought some changes and a heraldic coat tiled with lions painted. In the courtyard there was "a zoo of ephemeral life" [9]. 
Other reforms took place in the palace, but none of them was so significant as to change the architectural forms of Thays garden until 1950 (merits further deepening). Some pictures from 1950 are important to understand the landscape changes, even those occurred in the 1960s. The garden during this period was eclectic.

In 1968, a major intervention in the Lions Palace Garden was done by Roberto Burle Marx. The design of Roberto Burle Marx came with a modernist landscape proposal, which carried with it a statement of modernity, such as the political discourse of that time in the state of Maranhão.

Roberto Burle Marx, after 60 years of the twentieth century, became a disputed landscaper between the Brazilian authorities at that time. His hiring represented a distinction of status, not just for the garden that he worked, but for the authority that hired him. At that time of the history of the Brazilian public administration, they had no special legal regimes for hiring and spending of public money, giving the responsibility to the palace about how to deal with the spending money. Such aside, no witness against the brilliant work of Roberto Burle Marx, who both ecological and landscape achieved success in their projects. Only reveals a differentiated professional working condition, in which the landscape could explore numerous creative possibilities, and sometimes unlimited expenses. There are many projects and achievements that Roberto Burle Marx has developed throughout his career, and his creative competence is recognized. He was one of the greatest landscape painters of modernity and exponent of Brazilian modernism, with international recognition, not only for the design and implementation of their projects inspired by tropical flora and innovative landscape compositions. However, it is emphasized here that the signings clear of legal recruitment schemes, at a time when the creation of the Professional myths in Brazil, despite controversy, is a story not discussed even in academia and within the Brazilian architecture, and It must be written in the near future, because it was generally promoted by the proximity of the authors with the authorities or legitimized by a few tenders.

Roberto Burle Marx's intervention, in the Palace of the Lions, was appointed by Leenhardt [10] and Montero [11] and it is registered in the Roberto Burle Marx's own site. These authors relate three landscaping projects in São Luis, as follows: in 1968 - the Palace of the Lions Garden, headquarters of the State Government; in 1982 - the project of the Garden of Alcoa Alumin SA; and in 1985 - the project of the Coastal Avenue. The 1982 and 1985 projects were not built as Roberto Burle Marx's projects. Alcoa's access landscaping, today Alumar, in São Luís Island, was redesigned and implemented by the company of architects Harry Roitman and Reinaldo Marques and design of the Coastal Avenue in the northwest part of São Luis Island that was redesigned with a postmodernist layout, by the local architect.

The Palace of the Lions project has not been fully implemented according to the original project, in 1968. The intervention of Roberto Burle Marx in this garden took place in two stages. In 1968, when he developed the landscaping project that changed the existing eclectic garden setting until then, and in 1973, when he was called to complete its original design. 
The original design made by Roberto Burle Marx to the Palace of the Lions Garden brought changes in aspects as the form, and vegetable tenor. It had tanks and water features to get the water plants, to be built with variable depths. Flowerbeds for grassy vegetation and ground covering shrub and ceramic floor tile and stone floor. During this period, a new garden was created according to a Brazilian proposal. However, not all design elements were implemented at that time. Years later, in 1973, Roberto Burle Marx was called to finalize it as its original proposal, according to the testimony of the former First Lady of Maranhão State, Mrs. Eney Santana, obtained in 2008.

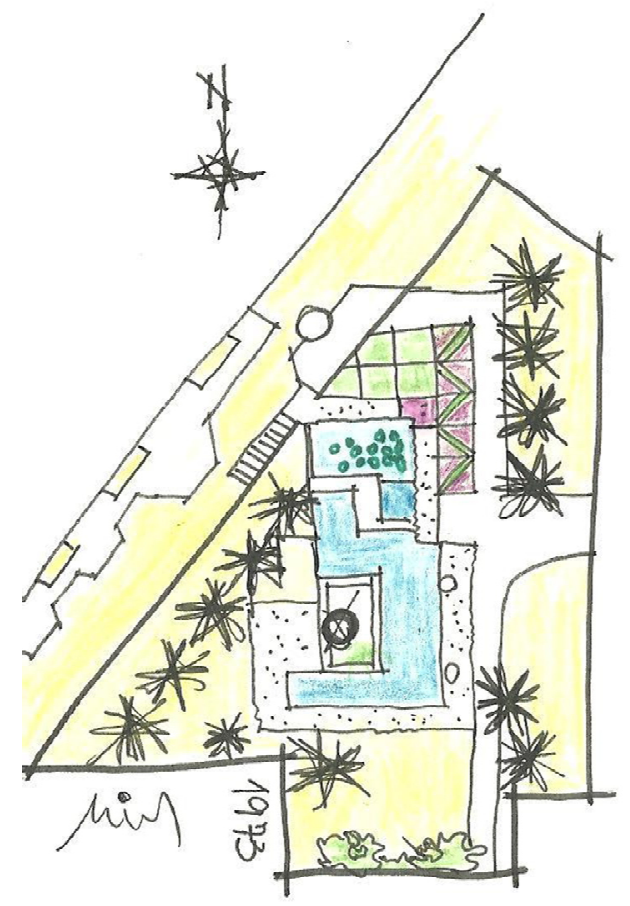

Figure 1: $\quad$ Sketch by Prado [3] about Roberto Burle Marx intervention in 1973 in the Palace of the Lions Garden observing the commemorative photography of Maranhão Government [14].

The architectural design feature brought interspersed frames forming full and empty from the textures and sheens, the "green and blue or green in every shade plants" as its landscape practices, explains Dourado [12].

In this garden "the reflected water contrasted with the brown and the gray of the floors" as well. The purpose of the garden was not intended as an imitation of nature. It followed what Burle Marx and Tabacow [13] describe: its gardens were "a chromatic event where volumes were connected and established relationships (...) strictly ordered and harmonically natural”. 
Public administrations that took place in Maranhão, did not defend the importance of the architectural complex properly. Despite the Architectural and Landscape Complex of São Luis city has been overturned in the book Tombo Arqueológico, Etnográfico e Paisagístico (free translation: Archaeological, Ethnographic and Landscape Tumble) in 1974 by the Federal Government through the IPHAN, and in December 4, 1997, the São Luis Historical Center has been awarded with the Cultural Heritage of Humanity title, the General Assembly of the UNESCO World Heritage Committee in Naples, the endcharacterization of changes and the whole works has not ceased. Vegetable collection was very disfigured and replaced.

The big change occurred in the reform of the palace in 1993, when Acacio Gil Borsoi's project released on 1992, replaced Roberto Burle Marx's project, with adaptations to create a pool where there was a tank for aquatic plants, loss of imperial palms and other plants and garden plants, no replacement of new samples, removal of plants and flowerbeds for parking of official cars and conducting social events, plus the withdrawal of palm trees to enlarge certain targeted.

The Palace of the Lions Garden is quoted on the architectural memories of Acacio Gil Borsoi, but there is no mention about the modernist project and the precedence of Roberto Burle Marx in the garden. In his memories, Borsoi comments on a solution that intended to implement the reform of 1993 to "create in the Noble Square its gardens and parking, an area that generates functional expansion area of the support staff to the governor and other services" [15].

"The various details added over the years were removed and create new solutions for everything to be integrated into the original design idea of Renaissance classic features" [15].

This solution for the national monument, was not performed, avoiding a greater distortion of it. But the gardens have undergone major changes rather than a well-deserved restoration.

Despite all this, the remains of the architectural landscaped collection of burlemarxian version can be recognized in a garden of Roberto Burle Marx, as the interlocking tanks, some cobblestone paths and tiles, and especially the design strength. Note that the mutilated-characterization parts of a whole, but the overall design still persists.

In the complex dialogue between the past and the future objective and subjective values which matter so much to the past, about the future of the Sao Luis society culture, it was hardly discussed in the interventions of landscape work of the Lions Palace Gardens. And contemporary adaptations to the personal tastes of the palace occupants of the national monument have been far from what should be strictly protected. 


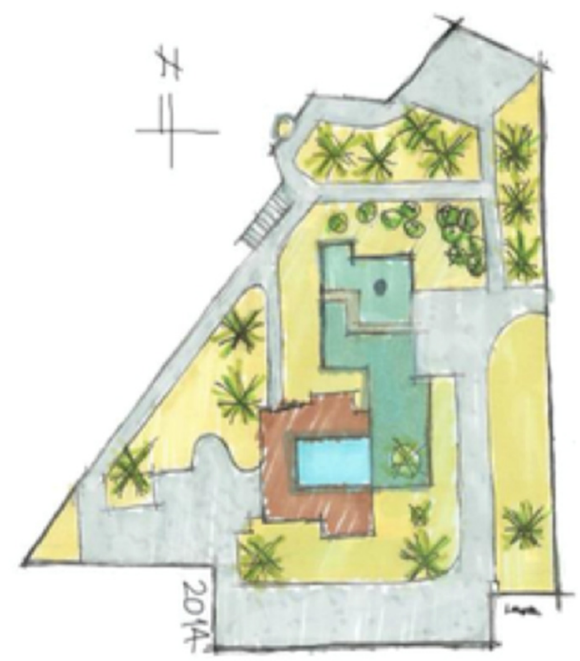

Figure 2: Sketch by Bernardes [16] about the state of art of the Palace of the Lions Garden.

\section{Conclusions}

The Palace of the Lions has undergone many recovering over the past 246 years. The Open Space was transformed from military use to the contemplative and recreational enjoyment of its occupants. In addition, is well-located, part of a historic area and part of the Palace of the Lions, the garden is also a free space that precedent to its own city of São Luis. The garden may well be one of the oldest Open Spaces of Brazil, since your space form a belvedere which contemplates the landscape of Sao Marcos Bay for more than four centuries and because its history is intertwined with the history of the fortress, the city and the Palace.

The letters preservation of Venice in 1964 and Florence in 1981 form arguments for the restoration of the original design, but the phenomenon of globalization from 1990, went on to invoke new values and replacing existing values.

The Roberto Burle Marx's garden in São Luis is very little known. It is still pointing in the main official forms of Maranhão. Similarly, it is located in public documentation files about the garden, which, however, is the beginning of Brazilian landscape architecture culture in Maranhão.

Both interventions of one of the greatest landscape painters of the 20th century point today, the historical, cultural and scenic value of the monumental Palace of the Lions Garden. For its location, landscape and history, the garden remains a clearance of outstanding importance for the Brazilian landscape architecture. 
On the one hand, this national monument has undergone numerous changes over time, on the other, its importance has been somewhat recognized by the government as it sought renowned architects to treat it. That point teaches us that it has prevailed government desire in harmony with hired architects, and so the risks of distortion are renewed every four years. Partly because some governments want to make their landmark, and because they do not understand that this is not just a space, but a national monument that lends itself to preservation of Brazilian history. When questioning which works should be preserved for the future, it is concluded that although other important contributions, the brand of Roberto Burle Marx work is the most significant, because it is a cultural asset, a heritage that expresses a Brazilian landscape, particular and unique, transcending the deliberations of local government and the individual wishes of professionals.

The work of Roberto Burle Marx deserves to be recovered, crystallized and preserved as it teaches other Brazilians about their cultural past.

\section{References}

[1] Magnoli, M. M. E. M. Espaços livres e urbanização: uma introdução a aspectos da paisagem metropolitana. Tese (Livre-docência). São Paulo: Faculdade de Arquitetura e Urbanismo, Universidade de São Paulo, 1982.

[2] Cullen, G. Paisagem Urbana. Lisboa: Edições 70, 1983.

[3] Prado, B. I. W. In: Carneiro, A. R. S. \& Silva, A. F. \& Silva, J. M. Jardins de Burle Marx no Nordeste do Brasil. Recife: Editora Universitária/UFPE, 137-158, 2013.

[4] Diário do Norte. Caderno do ano de 1901. Acervo da Biblioteca Pública Benedito Leite, 1901.

[5] Prado, B. I. W. Charles Thays na formação urbana de São Luís: a ilheidade de São Luís a partir da Praça Pedro II. Paisagem e Ambiente. 24: 69-80, 2007.

[6] Berjman, S. Plazas y Parques de Buenos Aires: la obra de los paisajistas franceses. Fondo de Cultura Económica de Argentina S.A., Buenos Aires, 1998.

[7] Costa, A. S. \& Prado, B. I. W. Charles Thays na formação urbana de São Luís: a ilheidade de São Luís a partir da Praça Pedro II. in: XVIII Seminário de Iniciação Científica da UEMA / I ${ }^{\mathrm{a}}$ Mostra de Práticas Investigativas de Pedagogia, São Luís, Brasil, 2006.

[8] Gazeta de Notícias. Caderno de 1901. Acervo da Biblioteca Nacional, 1901.

[9] Lima, C. Caminhos de São Luís. Sao Paulo: Editora Siciliano, 2002.

[10] Leenhardt, J. (Org.). Nos jardins de Burle Marx. Perspectiva, São Paulo, 1994.

[11] Montero, M.Í. Burle Marx: el paisaje lirico. Editoral Gustavo Gilli, Barcelona, 2001.

[12] Dourado, G. M. (Org.). Visões de Paisagem: Um Panorama do Paisagismo Contemporâneo no Brasil. ABAP, São Paulo, 1997. 
[13] Burle Marx, R.; Tabacow, J. Arte e Paisagem: conferências escolhidas. Studio Nobel, São Paulo, 2004.

[14] Maranhão. Palacio dos Leões. Departamento do Patrimônio Histórico, Artístico e Paisagístico. São Luís, 1975.

[15] Borsoi, A. G. Arquitetura como manifesto. Gráfica Santa Marta, Recife, 2006.

[16] Bernardes, L. S. In: Bernardes, L. S. \& Prado, B. I. W. Estudos para o projeto de restauração dos jardins do Palácio dos Leões: uma obra de Roberto Burle Marx - espécies vegetais e objetos de arte. (Studies for restoration project of Lions Palace Gardens: a work of Roberto Burle Marx - species plants and art objects). Pesquisa da Bolsa de Iniciação Cientifica da Universidade Estadual do Maranhão - PIBIC/UEMA, sob orientação de Profa. Dra. Barbara Irene Wasinski Prado. Artigo aprovado para apresentação.Teresina: $6^{\circ}$ Docomomo Norte Nordeste-Brasil 2016. 